\title{
A Novel Effector Protein, MJ-NULG1a, Targeted to Giant Cell Nuclei Plays a Role in Meloidogyne javanica Parasitism
}

\author{
Borong Lin, ${ }^{1}$ Kan Zhuo, ${ }^{1}$ Ping Wu, ${ }^{1}$ Ruqiang Cui, ${ }^{1,2}$ Lian-Hui Zhang, ${ }^{3}$ and Jinling Liao ${ }^{1}$ \\ ${ }^{1}$ Laboratory of Plant Nematology, South China Agricultural University, Guangzhou, China; ${ }^{2}$ College of Agronomy, JiangXi \\ Agricultural University, Nanchang 330045, China; ${ }^{3}$ Institute of Molecular and Cell Biology, 61 Biopolis Drive, Singapore \\ 138673
}

Submitted 16 May 2012. Accepted 22 June 2012.

\begin{abstract}
Secretory effector proteins expressed within the esophageal glands of root-knot nematodes (Meloidogyne spp.) are thought to play key roles in nematode invasion of host roots and in formation of feeding sites necessary for nematodes to complete their life cycle. In this study, a novel effector protein gene designated as Mj-nulg1a, which is expressed specifically within the dorsal gland of Meloidogyne javanica, was isolated through suppression subtractive hybridization. Southern blotting and BLAST search analyses showed that Mj-nulg1a is unique for Meloidogyne spp. A real-time reverse-transcriptase polymerase chain reaction assay showed that expression of Mj-nulgla was upregulated in parasitic second-stage juveniles and declined in later parasitic stages. MJ-NULG1a contains two putative nuclear localization signals and, consistently, in planta immunolocalization analysis showed that MJ-NULG1a was localized in the nuclei of giant cells during nematode parasitism. In planta RNA interference targeting Mj-nulgla suppressed the expression of Mj-nulgla in nematodes and attenuated parasitism ability of $M$. javanica. In contrast, transgenic Arabidopsis expressing Mj-nulgla became more susceptible to $M$. javanica infection than wild-type control plants. These results depict a novel nematode effector that is targeted to giant cell nuclei and plays a critical role in $M$. javanica parasitism.
\end{abstract}

Root-knot nematodes (RKN), such as Meloidogyne spp., are important obligate biotrophic plant parasites. They are one of the most damaging plant-parasitic nematodes, infecting more than 3,000 plant species from diverse plant families worldwide (Sasser 1980). In the process of infection, the second-stage juveniles (J2) of RKN penetrate into the elongation zone of host roots and migrate intercellularly and then to the vascular

\section{B. R. Lin and K. Zhuo contributed equally to this work}

Corresponding authors: J. L. Liao; E-mail address: jlliao@scau.edu.cn; and L. H. Zhang; E-mail address: lianhui@imcb.a-star.edu.sg

In this study, a 1,974-bp genomic fragment named Mj-nulgla (National Center for Biotechnology Information [NCBI] GenBank accession number JN836601) and a 274-amino-acid polypeptide (NCBI GenBank accession number AEI98921) were obtained.

* The $\boldsymbol{e}$-Xtra logo stands for "electronic extra" and indicates that five supplementary figures and one supplementary table are published online.

(C) 2013 The American Phytopathological Society cylinder, where the nematodes establish permanent feeding sites, called giant cells. These large, multinucleated feeding cells provide the nematodes with nutrients and are required for RKN development and reproduction (Bird et al. 2009; Wyss et al. 1992). Giant cell formation is caused by the effector proteins of RKN, which are originated from RKN esophageal gland cells and released into plant roots through their hollow, protrusible stylets. Effector proteins transform five to seven root vascular cells into hypertrophied multinucleate giant cells by inducing repeated nuclear division without cytokinesis (Huang et al. 2006b; Hussey 1989; Jaubert et al. 2004). The RKN effectors are thought to play key roles in parasitism, not only in feeding site formation and maintenance but also in host penetration (Davis et al. 2000; Hussey 1989).

Over the past decade, numerous studies were conducted to identify secretory effector proteins from RKN. These include a range of cell-wall-degrading enzymes such as $\beta$-1,4-endoglucanase (Ledger et al. 2006; Rosso et al. 1999; Zhang et al. 2006a), pectate lyase (Doyle and Lambert 2002; Huang et al. 2005a), polygalacturonase (Jaubert et al. 2002a), $\beta$-1,4-endoxylanase (Dautova et al. 2001), and cellulose-binding protein (Ding et al. 1998). Other effectors include chorismate mutase (Huang et al. 2005b; Lambert et al. 1999; Long et al. 2006a and b), venom allergen-like protein (Ding et al. 2000; Wang et al. 2007), glutathione S-transferase (Dubreuil et al. 2007), acid phosphatase, and sodium/calcium/potassium exchanger (Huang et al. 2003). Many novel effectors were identified through microaspiration of esophageal gland cells (Huang et al. 2003). Direct analysis of effector proteins was also conducted at the protein level. A calreticulin from Meloidogyne incognita was separated by two-dimensional electrophoresis and identified by microsequencing (Jaubert et al. 2002b). Recently, 486 proteins secreted by $M$. incognita were directly identified using mass spectrometry (Bellafiore et al. 2008). Furthermore, genomic DNA sequences of $M$. incognita and $M$. hapla have been published (Abad et al. 2008; Opperman et al. 2008), which provide the possibility to identify RKN effector proteins through bioinformatics. Similarly, a secretome of Plasmodium falciparum comprising 200 proteins was predicted using bioinformatics (van Ooij et al. 2008). However, in order to increase our understanding of the molecular mechanisms of RKN parasitism, it is important to conduct further studies to explore the functions of these effector proteins.

$M$. javanica is one of most common Meloidogyne spp. worldwide and a major agricultural pest in many countries (Sasser 1980). Currently, only very few effector proteins from $M$. javanica have been identified, including cell wall-degrading 
enzymes such as $\beta$-1,4-endoglucanase (Zhang et al. 2006a), pectate lyase (Doyle and Lambert 2002), and the putative pathogenicity factor MJAP (Adam et al. 2009). In our preliminary study, suppression subtractive hybridization ( $\mathrm{SSH}$ ) was used to investigate the transcriptome differences between egg and J2, two distinct life stages of $M$. javanica. The investigation led to identification of a 436-bp expressed sequence tag (EST), which was substantially upregulated at the $\mathrm{J} 2$ stage of $M$. javanica. BLASTn searches revealed that it shares a high similarity to Meloidogyne EST but no sequence similarity was noted when searched against other organisms. Here, we report the isolation and molecular analysis of the full-length gene specific to the 436-bp EST. The gene was named Mj-nulgla because its peptide product possesses two predicted nuclear localization signals (NLS), suggesting that it might be a nuclear localized protein (NULG). We further analyzed the spatial and developmental expression patterns of Mj-nulgla. In addition, we also investigated the in planta secretion of $\mathrm{MJ}$ NULG1a and examined the role of MJ-NULG1a in $M$. javanica parasitism in tomato using in planta RNA interference (RNAi) and overexpression approaches.

\section{RESULTS}

\section{Identification and sequence analysis of the Mj-nulgla gene} from $M$. javanica.

Based on the cDNA sequence of the 436-bp EST identified through SSH analysis (Supplementary Fig. S1A), a 1,974-bp genomic fragment (National Center for Biotechnology Information [NCBI] GenBank accession number JN836601) named $M j$-nulgla was obtained by thermal asymmetrical interlaced (TAIL) polymerase chain reaction (PCR) and rapid amplification of cDNA ends (RACE). The gene Mj-nulgla contains an open reading frame (ORF) of $825 \mathrm{bp}$, interrupted by two introns of 259 and $406 \mathrm{bp}$ in length. The intron/exon boundaries have a conserved 5'-GT-AG-3' intron splice-site junction (Mount 1982). The genomic sequence includes 365-bp 5' upstream and 119-bp 3' downstream sequences. An initiation site (Inr) (5'-CCAGTTT-3') and a putative TATA element (5'-TAT AAAA-3') were located 41 to 47 and 77 to $83 \mathrm{bp}$, respectively, upstream of the ATG start codon which constitute a core promoter. However, no CAAT sequence, which is the binding site for the RNA transcription factor, was present in the promoter region. The $3^{\prime}$-untranslated region contained a typical polyadenylation signal (5'ATAAA-3') located 109 to 113 bp downstream of the TAA stop codon.

A BLAST search did not reveal any significant $M j$-nulgla homologues at either nucleotide or peptide level in other organisms. However, the same search against the EST database revealed similar EST from several RKN, including $M$. paranaensis, $M$. javanica, $M$. arenaria, $M$. incognita, $M$. hapla, and M. chitwoodi (the lowest match was CB856028 of M. chitwoodi, with approximately $72 \%$ identity at nucleotide level). In particular, the EST database of $M$. javanica contains 30 EST showing similarity to Mj-nulgla. Among them, 23 EST can be integrated as a contig of $710 \mathrm{bp}$, which shows $99.7 \%$ identity to $M j$-nulgla. The remaining seven EST form a contig of $713 \mathrm{bp}$, which showed approximately $95.8 \%$ identity to $\mathrm{Mj}$-nulgla.
Hence, we concluded that $M$. javanica may contain two highly conserved $M j$-nulgla alleles.

The ORF of Mj-nulgla was translated into a peptide of 274 amino acids (aa) (NCBI GenBank accession number AEI98921), with a calculated molecular mass of $31.56 \mathrm{kDa}$ and an isoelectric point (pI) at 8.22, as predicted by the ProtParam server. The protein contains a putative a hydrophobic signal peptide at the $\mathrm{N}$ terminal, with the signal sequence cleavage site located between 19 and 20 aa, as shown by SignalP. According to PSORT II (Kalderon et al. 1984), MJ-NULG1a contains two putative SV40-like NLS domains (i.e., ${ }^{140} \mathrm{PKKE}$ $\mathrm{KPK}^{146}$ and ${ }^{167} \mathrm{PKKTKPA}^{173}$ ), suggesting a high probability to be localized in the nucleus compared with other possible subcellular destinations. To obtain more robust predictions about subcellular destinations, the PSORT II analysis was complemented by WoLF PSORT. Similarly, MJ-NULG1a without its signal peptide was predicted to be accumulated most likely in the nucleus (Table 1).

\section{Mj-nulgla is conserved in Meloidogyne spp.}

To understand how well Mj-nulgla is conserved in nematodes, Southern blotting analysis was conducted using total DNA samples from $M$. javanica, $M$. enterolobii, $M$. incognita, Heterodera glycines, Bursaphelenchus xylophilus, and Caenorhabditis elegans. The total DNA samples from Meloidogyne spp. were separately digested with EcoRI and XbaI and hybridized with the digoxigenin (DIG)-labeled full-length $M j$ nulgla DNA probe. The results unveiled two and four strong hybridizing bands from the EcoRI- and XbaI-digested $M$. javanica samples, respectively (Fig. 1, lanes 1 and 2). Given that EcoRI does not have a cleavage site and XbaI has one cleavage site only in $M j$-nulgla DNA, the results indicate that the $M$. ja-

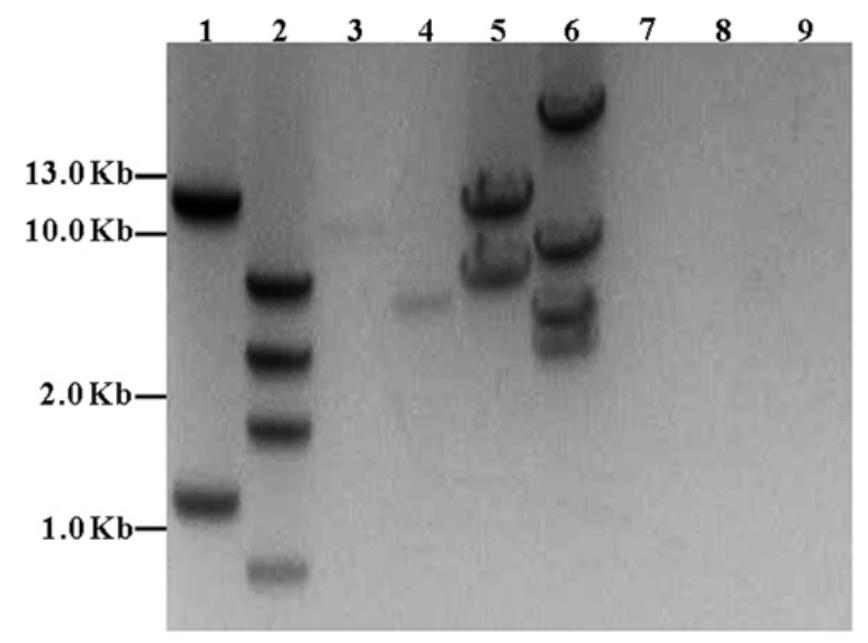

Fig. 1. Southern blot analysis of Mj-nulgla. Lanes 1 and 2, $10 \mu \mathrm{g}$ of DNA from Meloidogyne javanica digested with EcoRI and $\mathrm{XbaI}$, respectively; lanes 3 and 4: $10 \mu \mathrm{g}$ of DNA from $M$. enterolobii digested with EcoRI and $X b a \mathrm{I}$, respectively; lanes 5 and 6: $10 \mu \mathrm{g}$ of DNA from $M$. incognita digested with EcoRI and $X b a \mathrm{I}$, respectively; lanes 7, 8, and 9: $10 \mu \mathrm{g}$ of DNA from Heterodera glycines, Bursaphelenchus xylophilus, and Caenorhabditis elegans, respectively, digested with EcoRI. All samples were probed with the digoxigenin-labeled full-length $M j$-nulgla DNA.

Table 1. Predicted nuclear localization signal (NLS) domains and localization of MJ-NULG1a

\begin{tabular}{lcl}
\hline Predicted NLS $^{\mathbf{a}}$ & NLS type & \multicolumn{1}{c}{ PSORT II $^{\mathbf{b}}$} \\
\hline${ }^{140}$ PKKEKPK $^{146}$ & SV40 & WoLF PSORT $^{\mathbf{c}}$ \\
${ }^{167}$ PKKTKPA $^{173}$ & SV40 & Nucleus 72\%; mitochondrial matrix \\
\hline
\end{tabular}

${ }^{a}$ NLS domain as predicted by PSORT II.

b PSORT prediction with likelihood of subcellular localization.

${ }^{c}$ Number of nearest neighbors for subcellular compartments as predicted by WoLF PSORT. 
vanica genome contains two Mj-nulgla alleles, which is highly agreeable with the above-described EST contig analysis. Similar numbers of strong hybridizing bands were also found in the genome samples from $M$. incognita (Fig. 1, lanes 5 and 6). In contrast, only one weak hybridizing band was noted in the $M$. enterolobii DNA sample (Fig. 1, lanes 3 and 4), which may suggest a low sequence similarity. However, not any hybridizing band was found in the EcoRI-digested DNA samples from three non-Meloidogyne spp.; that is, H. glycines (Fig. 1, lane 7), B. xylophilus (Fig. 1, lane 8), and C. elegans (Fig. 1, lane 9). These results together with BLAST search data seem to suggest that Mj-nulgla alleles might exist only in RKN.

\section{Anti-MJ-NULG1a serum specifically reacts with MJ-NULG1a.}

The antiserum against MJ-NULG1a was prepared using the purified MJ-NULG1a protein. Western blots were used to determine the serum specificity to MJ-NULG1a. The sodium dodecyl sulfate polyacrylamide gel electrophoresis (SDS-PAGE) showed that the recombinant MJ-NULG1a with an N-terminal his-tag was well purified, with only one band of approximately 33-34 kDa observed, which is within the range of calculated size $(33 \mathrm{KDa})$ of the recombinant MJ-NULG1a (Supplementary Fig. S2). An aliquot of rabbit pre-immune serum was collected and used as a control. Total protein samples were prepared from $\mathrm{J} 2$ of $M$. javanica, the galls from tomato at 7 days after inoculation with $M$. javanica, and uninoculated healthy tomato roots. Western blot using MJ-NULG1a antiserum showed a clear hybridizing band with the expected size of MJNULG1a protein in the total protein samples from $\mathbf{J} 2$ and nematode-containing tomato galls but not in the protein sample from healthy tomato roots (Fig. 2). In contrast, the control Western blot hybridized with pre-immune serum did not produce any visible band from the nematode and tomato total protein samples (Fig. 2). The results indicate that the antiserum against MJ-NULG1a specifically recognizes an antigen in the total protein samples from the nematodes and nematodeinfected host tissues.

\section{MJ-NULG1a is expressed}

in the dorsal esophageal gland and upregulated

in the early parasitic stage of the nematode.

Anti-MJ-NULG1a serum was used for immunolocalization experiments to investigate the spatial positioning of $\mathrm{MJ}$ NULG1a in M. javanica. A strong signal was observed within

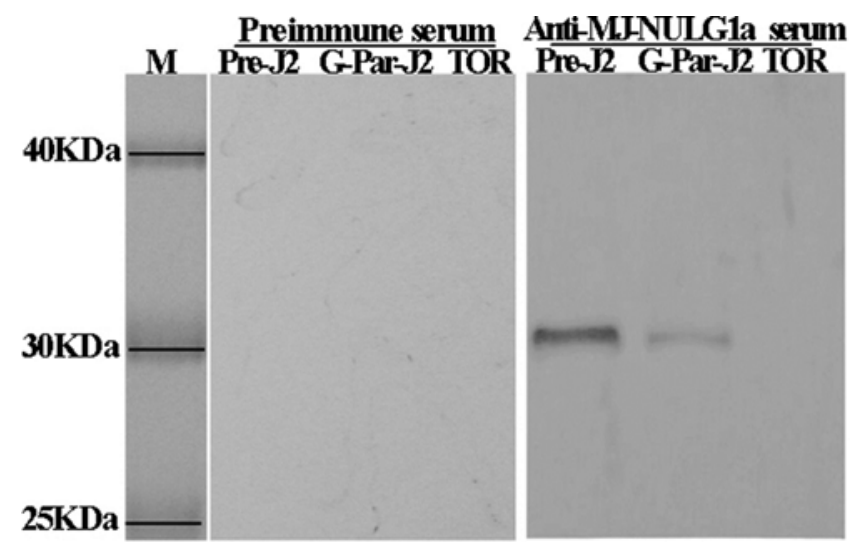

Fig. 2.Western blot of preparasitic second-stage juvenile J2 (pre-J2), galls containing parasitic second-stage juvenile (G-par-J2), and healthy tomato roots (TOR) total protein with anti-MJ-NULG1a serum. Total proteins $(10 \mu \mathrm{g})$ from pre-J2, G-par-J2, and TOR were loaded in each lane. Blots were probed with pre-immune serum (left) or anti-MJ-NULG1a serum (right). the dorsal gland cells of preparasitic J2 (Fig. 3A) and parasitic nematodes (isolated from tomato galls 10 days postinoculation) treated with anti-MJ-NULG1a serum (Fig. 3B) but no signal was observed in control samples incubated with preimmune serum (Fig. 3C). The transcriptional expression of $M j$-nulgla was analyzed by real-time PCR in different developmental stages of $M$. javanica. Mj-nulgla was found to be upregulated in the early par-J2. In par-J2 stages (i.e., at 2 and 5 days postinfection [dpi] with $M$. javanica), the transcripts of $M j$-nulgla increased gradually and reached a maximum at 5 dpi, a sevenfold increase in expression compared with the preparasitic J2 (pre-J2) stage. After that, the transcript level of $M j-n u l g l a$ was gradually reduced and reached a minimum at the female stages, where only one-eighth of the transcript level was found compared with the transcripts in pre-J2 (Fig. 4). The findings suggest that $M j$-nulgla may play a primary role during the early stages of nematode parasitism.

MJ-NULG1a is localized in the nuclei of tomato plant cells.

To test the localization of MJ-NULG1a in plant cells, a protein transient expression assay was performed. The full-length Mj-nulgla cDNA sequence and the truncated Mj-nulgla cDNA without the signal peptide-coding sequence was fused in frame with the coding sequence of green fluorescent protein (GFP),
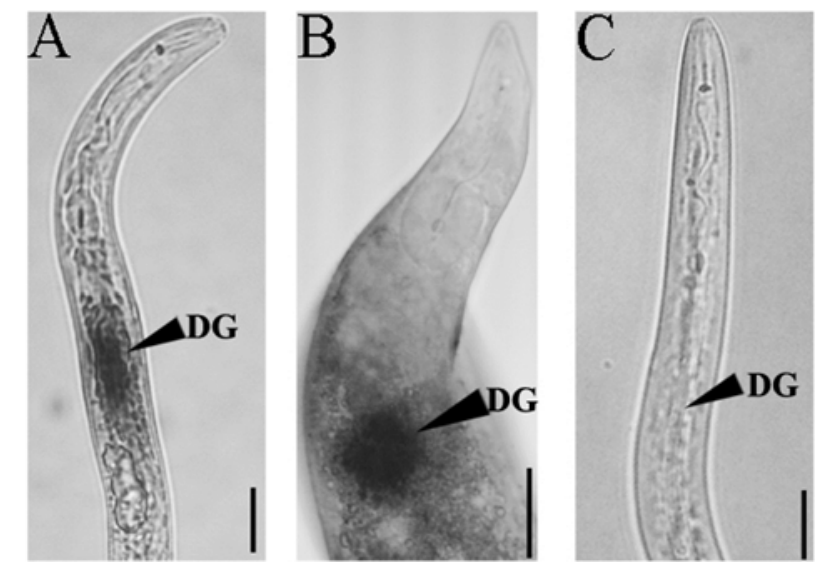

Fig. 3. Immunolocalization of MJ-NULG1a in nematodes. A, Preparasitic second-stage juvenile (pre-J2); B, parasitic third-stage juvenile (par-J3), showing the protein located in dorsal gland cells; $\mathbf{C}$, absence of signal in pre-J2 incubated with pre-immune serum. DG, dorsal gland cells. Scale bars $=10 \mu \mathrm{m}$.

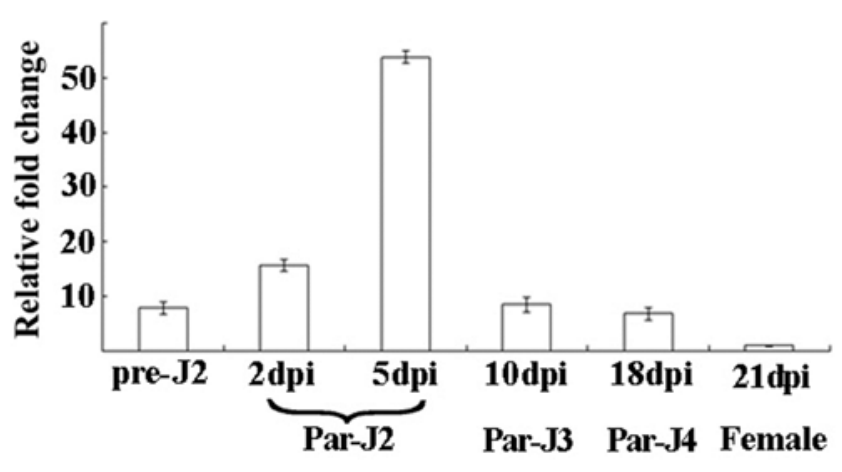

Fig. 4. Developmental expression pattern of Mj-nulgla. The relative expression level of $M j$-nulgla was quantified using quantitative polymerase chain reaction in six different Meloidogyne javanica stages. Fold change values were calculated using the $2^{-\triangle \Delta C T}$ method and presented as the change in mRNA level in various nematode developmental stages as indicated, relative to that of female; dpi = days postinfection. Each column represents the mean of three independent experiments with standard deviation. 
and placed under the control of double Cauliflower mosaic virus (CaMV) 35S promoter (Supplementary Fig. S3). The CaMV35S promoter-driven GFP expression construct was also prepared and used as a control. The constructs were introduced into tomato cotyledon epidermal cells through Agrobacterium-based transformation (Li et al. 2009). At $48 \mathrm{~h}$ after Agrobacterium tumefaciens inoculation, the fusion product without signal peptide of MJ-NULG1a showed a strong fluorescence signal in plant nuclei (Fig. 5A). However, the fusion product with signal peptide of MJ-NULG1a was observed only in plant cell-wall regions (Fig. 5B). As expected, GFP fluorescence was visible in the whole cell when GFP was expressed alone (Fig. 5C), and no fluorescence signal was detected in the untransformed control tomato cells (Fig. 5D). The above data suggest that $\mathrm{MJ}$ NULG1a would be imported into the plant cell nucleus following delivery into the cytoplasm of host cells by the nematode.

\section{MJ-NULG1a is targeted to nuclei of giant cells during nematode parasitism.}

To further investigate MJ-NULG1a localization at different stages of parasitism, immunolocalization was performed on the gall sections from tomato plants at 5 (par-J2), 10 (par-J3), 18 (par-J4), and 21 (female) dpi with $M$. javanica. The hybridization signals were observed in giant cell nuclei and along the cell wall of adjacent giant cells at 5, 10, and 18 dpi with $M$. javanica (Fig. 6A, B, and C, respectively). At $21 \mathrm{dpi}$, no signal was observed in giant cell nuclei but some signals were found

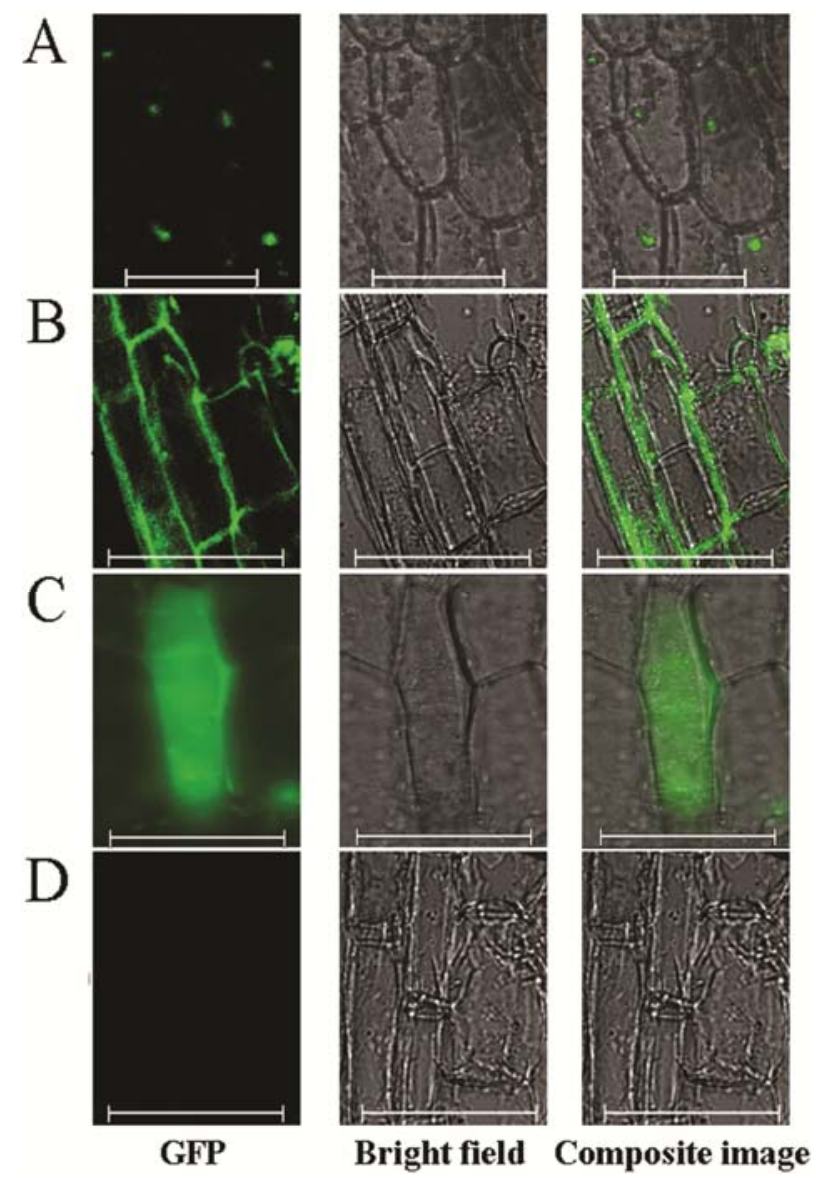

Fig. 5. Subcellular localization of MJ-NULG1a. Mj-nulg1a cDNA with or without signal peptide-coding sequence was fused to green fluorescent protein (GFP) reporter protein and expressed in tomato epidermal cells. A, GFP signal in cell nuclei (fusion protein without peptide); B, GFP signal in the cell wall regions (fusion protein with signal peptide); $\mathbf{C}$, GFP signal in the whole cells (GFP alone); D, no GFP signal in wild type tomato epidermal cells, used as a negative control. Scale bars $=50 \mu \mathrm{m}$. in cell-wall regions (Fig. 6D). No signal was observed in the giant cells of gall sections containing $\mathrm{J} 3$ without hybridization (Fig. 6E) or incubated with pre-immune serum (Fig. 6F), and in root sections of an uninfected healthy plant hybridized with anti-MJ-NULG1a serum (Fig. 6G).

These findings suggest that MJ-NULG1a could be secreted by all three juvenile stages during parasitism, injected into host plants, and targeted to the cell nucleus.

\section{In planta RNAi}

of $M j$-nulgla attenuates nematode parasitism.

In order to determine the nematode phenotype after silencing Mj-nulgla, Tobacco rattle virus (TRV)-mediated gene silencing was performed to knock down the target gene during parasitism. Two DNA fragments were amplified from the $\mathrm{N}$ terminal and $\mathrm{C}$ terminal of $M j$-nulgla cDNA and named $n \lg ^{1 \mathrm{st}}(319 \mathrm{bp})$ and $n u \lg ^{2 \mathrm{nd}}$ (304 bp), (Supplementary Fig. S5), which were separately cloned in TRV vector pTRV2 to generate the expression constructs pTRV::nulg ${ }^{1 \text { st }}$ and pTRV::nulg ${ }^{2 \text { nd }}$. The two constructs, together with pTRV control, were introduced into tomato plants through co-agroinfiltration with $A$. tumefaciens, respectively. Semi-quantitative reverse-transcriptase (RT)-PCR analysis using the nematode $\beta$-actin gene as internal control showed that the transcript level of $M j$-nulgla displayed a drastic reduction in nematodes at 5 dpi in both the TRV2::nulg ${ }^{1 \text { st }}$ - and TRV2::nulg ${ }^{2 \text { nd }}$-infiltrated plants compared with the TRV2-infiltrated plants and noninfiltrated tomato plants (Fig. 7A and B), demonstrating the effectiveness of in planta RNAi-mediated gene silencing.

The TRV2::nulg ${ }^{1 \text { st }}$ - and TRV2::nulg ${ }^{2 \text { nd }}$-infiltrated tomato plants had fewer nematodes, galls, and eggs in the roots than noninfiltrated plants or plants infiltrated with TRV2. The average number of nematodes in the roots displayed a reduction of 72.7 to 84.8 and 63.6 to $88.8 \%$ in the TRV2::nulg ${ }^{1 \text { st }}$ and TRV2::nulg ${ }^{\text {2nd }}$ lines, respectively, compared with TRV2, and a reduction of 76.9 to 84.5 and 69.2 to $87.3 \%$, respectively, compared with noninfiltrated plants on various days postinoculation (Fig. 7C). Similar significant reductions were also found in the average numbers of galls and eggs in TRV2::nulg ${ }^{1 \mathrm{st}}$ - and TRV2::nulg ${ }^{\text {2nd }}$-infiltrated plants compared with the TRV and noninfiltrated controls (Fig. 7D and E). These in planta RNAi findings suggest a critical role of MJ-NULG1a in nematode parasitism.

\section{Expression of $\mathrm{Mj}$-nulg1a \\ in Arabidopsis increases susceptibility to M.javanica.}

To further verify the findings of RNAi, we tested the impact of Mj-nulgla expression in planta on parasitism of $M$. javanica. The truncated $M j$-nulgla cDNA without signal peptide driven by a double CaMV35S promoter was expressed in Arabidopsis. The presence of expressed $M j$-nulgla transcripts in the transformed Arabidopsis lines was confirmed by RTPCR analysis (Fig. 8A). Phenotype analysis of transgenic plants indicated that $M j$-nulgla expression had no apparent effect on plant growth and development. Two independent homozygous T3 lines (lines OE05-11 and OE17-04) expressing Mj-nulgla were used in nematode infection assays. A clear effect of transgene expression on nematode susceptibility was observed. Both transgenic lines became significantly $(P<0.05)$ more susceptible to $M$. javanica infection than wild-type Arabidopsis, which is evident in the increased number of nematodes inside the roots at 18 and 42 dpi (Fig. 8B) and galls at 42 dpi (Fig. 8C).

\section{DISCUSSION}

Effector proteins synthesized in the esophageal gland cells of plant-parasitic nematodes and secreted into a host plant are 

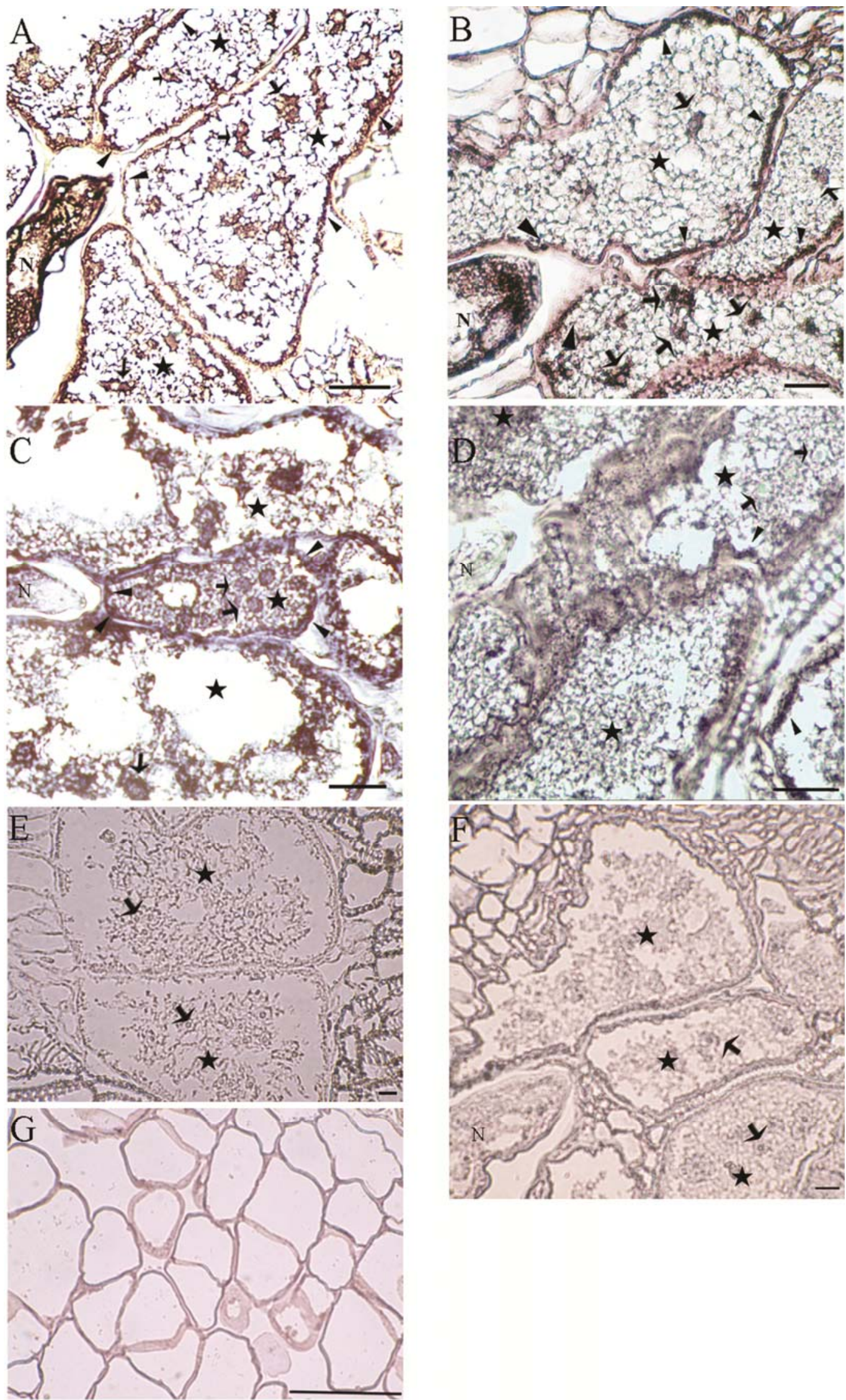

Fig. 6. MJ-NULG1a localization in sectioned tomato galls. A to C, Gall containing a second-stage juvenile (J2) at 5 days postinfection (dpi), a third-stage juvenile (J3) at $10 \mathrm{dpi}$ and a fourth-stage juvenile (J4) at $18 \mathrm{dpi}$, showing the protein at the cell wall of adjacent giant cells (arrowhead) and giant cell nuclei (arrow). D, Gall containing a female at $21 \mathrm{dpi}$, showing the protein at the cell wall of adjacent giant cells (arrowhead) but no signal in giant cell nuclei; E, gall without any treatment at $18 \mathrm{dpi}$, showing no signal; F, gall containing a J3 incubated with pre-immune serum, showing no signal; G, healthy tomato roots incubated with anti-MJ-NULG1a serum, showing no signal. N, nematode; asterisks, giant cells. Scale bars $=10 \mu \mathrm{m}$. 
thought to mediate nematode infection and parasitism of plants (Williamson and Hussey 1996). In this study, we report a novel effector protein (MJ-NULG1a) from $M$. javanica. MJ-NULG1a contains putative NLS and most likely accumulates in plant cell nuclei. Nematode effector proteins targeting the plant nucleus are among several types of key proteins that have been predicted to play an important role in regulating the plant cell cycle in host nucleus for successful parasitism (Bellafiore et al. 2008; Davis et al. 2004; Elling et al. 2007). Fifteen $H$. glycines glandexpressed gene products were predicted to contain NLS and believed to be targeted into the plant cell nucleus (Gao et al. 2003). Eight of these genes were further used to create translational fusion proteins with GFP and $\beta$-glucuronidase (GUS) coding sequences to test the predicted nuclear localizations (Elling et al. 2007). In another Heterodera sp., H. schachtii, a ubiquitin extension protein has been reported to be imported into plant nucleoli (Tytagat et al. 2004). In another cyst nematode, Globodera pallida, there were several members of the SPRYSEC family of proteins showing subcellular localization patterns in plant cell nuclei deduced from overexpression assays (Jones et al. 2009). In Meloidogyne spp., the effector proteins from M. incognita containing NLS have previously been reported and suggested to be targeted to the nucleus (Huang et al. 2003). In a subsequent study, weak nuclear accumulation was observed for two $M$. incognita 14-3-3 protein homologues (Jaubert et al. 2004). A small secretory peptide from $M$. incognita was shown to interact with two plant SCARECROW-like transcription factors in planta (Huang et al. 2006b). Recently, 66 secreted proteins from
M. incognita with putative nuclear localization, DNA binding, or chromatin modification domains were identified, which include helicases, RNA and DNA binding proteins, histones, and the nucleosome assembly protein 1 (Bellafiore et al. 2008). In addition, three esophageal gland-specific parasitism proteins from $M$. chitwoodi have been predicted to be located in the host cell nucleus (Roze et al. 2008). While this article was in preparation, Jaouannet and associates (2012) published a paper online that showed the in planta localization of the $M$. incognita effector protein Mi-EFF1 in giant-cell nuclei. Intriguingly, none of these known effector proteins have any significant similarity to MJ-NULG1a.

It is believed that signal peptide-containing effector proteins are imported cotranslationally into the endoplasmic reticulum of the nematode esophageal gland cells, where cleavage of the signal peptide occurs, and the mature proteins are secreted to host plant tissue via the nematode stylet (Elling et al. 2007; Sacco et al. 2009). Consistent with the above notion, strong GFP fluorescence signals were observed in tomato cell nuclei when the MJ-NULG1a-GFP fusion protein without signal peptide was used in the Agrobacterium-based transient expression assay. As predicted, when using the fusion proteins containing the native signal peptide of MJ-NULG1a, GFP fluorescence was observed in cell-wall regions. These results indicate that, once the protein is delivered to the cytoplasm by the nematode, it can be targeted into host cell nuclei.

Accumulation of MJ-NULG1a in host cell nuclei was further confirmed by in planta immunolocalization, which has

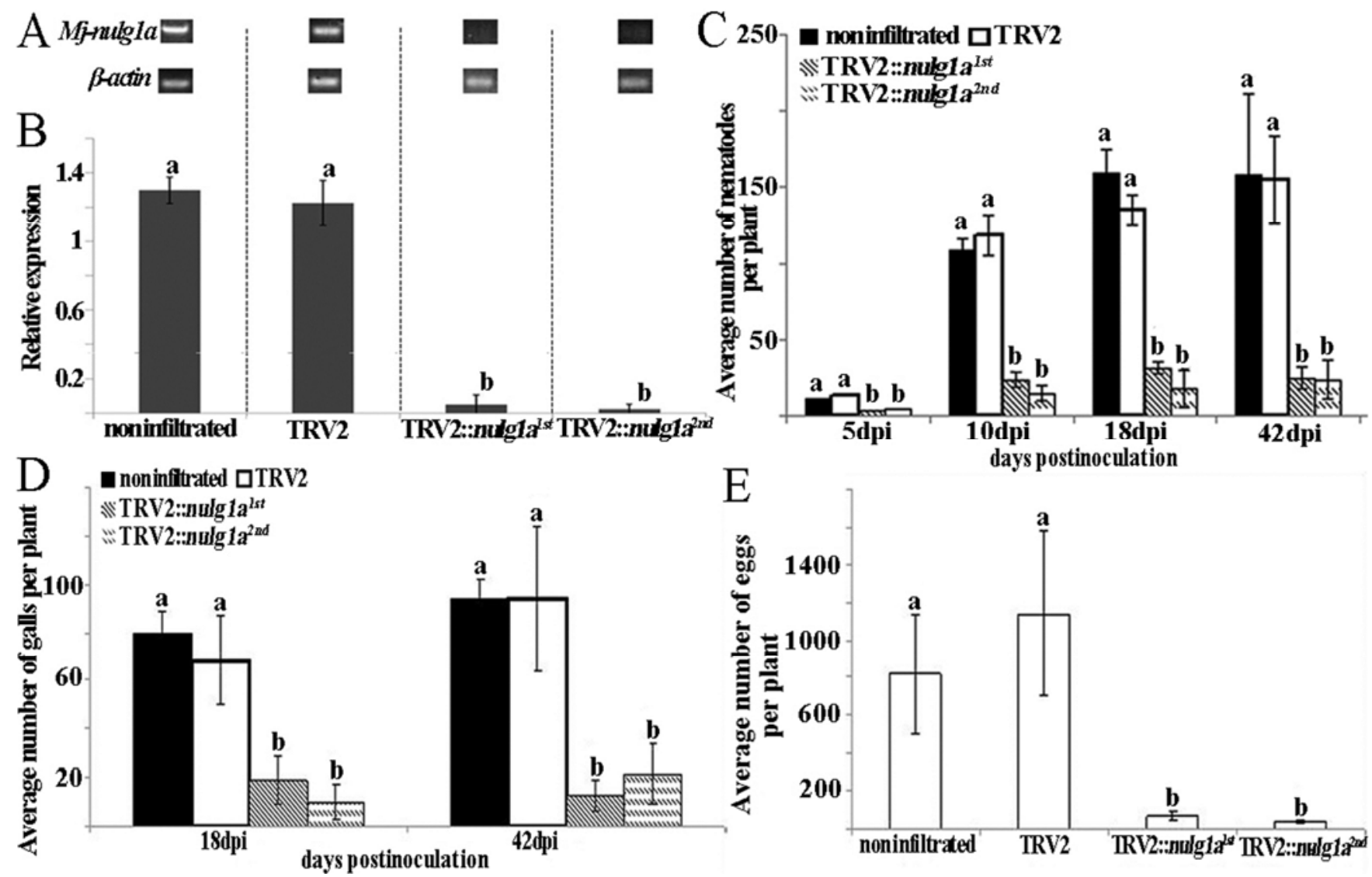

Fig. 7. Effect of in planta RNAi of Mj-nulg1a on Meloidogyne javanica. A, Reverse-transcriptase polymerase chain reaction (RT-PCR) assays for expression levels of $M j$-nulg1a in $M$. javanica collected from noninfiltrated tomato plants and pTRV2, pTRV2::nulg1 $1 a^{1 \mathrm{st}}$, and pTRV2::nulg1 $a^{2 \mathrm{nd}}$ agroinfiltrated plants; $\beta$-actin was amplified as control. B, Relative expression of Mj-nulg1a in M. javanica collected on noninfiltrated tomato plants, pTRV2, pTRV2::nulg1a1st, and pTRV2::nulg1 $a^{2 \text { nd }}$ agroinfiltrated plants. Values of relative expression were converted by dividing the amount of Mj-nulgla by the amount of the control gene $\beta$-actin. $\mathbf{C}$ and $\mathbf{D}$, Number of nematodes and galls, respectively, in the tomato roots at various days postinoculation (dpi), as indicated. E, Number of eggs at 42 dpi. Each column represents the mean of three independent experiments with standard deviations. Columns for the same time point or treatment marked with different letters are significantly different $(P<0.05)$ from each other. RT-PCR experiments were repeated twice with similar results. 
previously been used for study of the in planta localization of several effector proteins, including calreticulin from $M$. incognita and HgCLE from $H$. glycines (Jaubert et al. 2005; Wang et al. 2010). Our results showed that MJ-NULG1a was secreted into tomato and targeted to giant cell nuclei, which is consistent with the results from the transient expression assay.

It was noticed that the MJ-NULG1a signal was also observed in the cell-wall regions at all nematode parasitic stages, and even in the cell-wall regions farthest from the nematode head. RKN effector proteins were previously shown to be detected in the apoplasm of infected tissues, mainly around the head of the nematode, as is the case of several effector proteins from $M$. incognita (Vieira et al. 2010). Interestingly, the effector proteins from the fungal pathogen Magnaporthe oryzae was shown capable of further moving into uninvaded neighbors after translocation to rice cytoplasm (Khang et al. 2010), and the authors suggested that this cell-to-cell movement may be required for preparing host cells before invasion. With all this considered, it is possible that the effector MJ-NULG1a is secreted into plant cells first, then targeted to the plant nucleus; meanwhile, some of the effector proteins may also be delivered into apoplast and adjacent cells. Alternatively, MJNULG1a may be secreted into the plant intercellular space first and moved through the intercellular spaces to enter host cells like oomycete and fungal effectors (Kale and Tyler 2011). Regardless of the route of MJ-NULG1a translocation, our results have provided solid evidence that the effector protein has been targeted into the cell nucleus during the process of nematode parasitism.

Quantitative RT-PCR analysis of Mj-nulgla transcripts showed that $M j$-nulgla plays a primary role in the early stages of nematode parasitism. Its expression level was significantly boosted at $2 \mathrm{dpi}$, reached a maximum level at $5 \mathrm{dpi}$, reduced subsequently, and became hardly detectable at 21 dpi (the female stage). The data are highly consistent with the role of MJ-NULG1a in parasitism, as discussed below. However, weak MJ-NULG1a signals could still be found in the cell-wall regions of giant cells at the female stage. A plausible explanation is that MJ-NULG1a is relatively stable in apoplast and the detected proteins were from early parasitic stages.

The BLAST results indicate that Mj-nulgla is conserved and specific in RKN species, which is confirmed by Southern blot analysis. A spatial expression analysis showed that $\mathrm{Mj}$ nulgla was expressed in the dorsal gland of Meloidogyne javanica. The content and activity of plant nematode esophageal gland cells could change throughout the parasitic cycle. The subventral glands are more active during nematode penetration and migration in roots, whereas the dorsal gland is more important for the formation and maintenance of a nematode feeding site (NFS) throughout the sedentary nematode life stages (Davis et al. 2008). Therefore, Mj-nulgla may likely play a role in formation and maintenance of the NFS, in particular in formation of giant cells during the early parasitic stage.

RNAi has been shown to reduce the expression of a range of plant nematode genes and is a powerful tool for functional analysis of nematode genes (Rosso et al. 2009). By using in planta RNAi, silencing of $M j$-nulgla in nematodes resulted in fewer galls, eggs, and parasitic nematodes in roots than in the control group, thereby suggesting a key role of MJ-NULG1a in nematode parasitism. In addition to the RNAi analyses, we also used a gene overexpression approach, which has also been frequently used to study the roles of nematode parasitism genes (Hamamouch et al. 2012; Hewezi et al. 2008, 2009; Patel et al. 2010). Highly agreeable with the RNAi data, constitutive expression of the Mj-nulgla gene in Arabidopsis rendered plants more susceptible to infection of $M$. javanica,

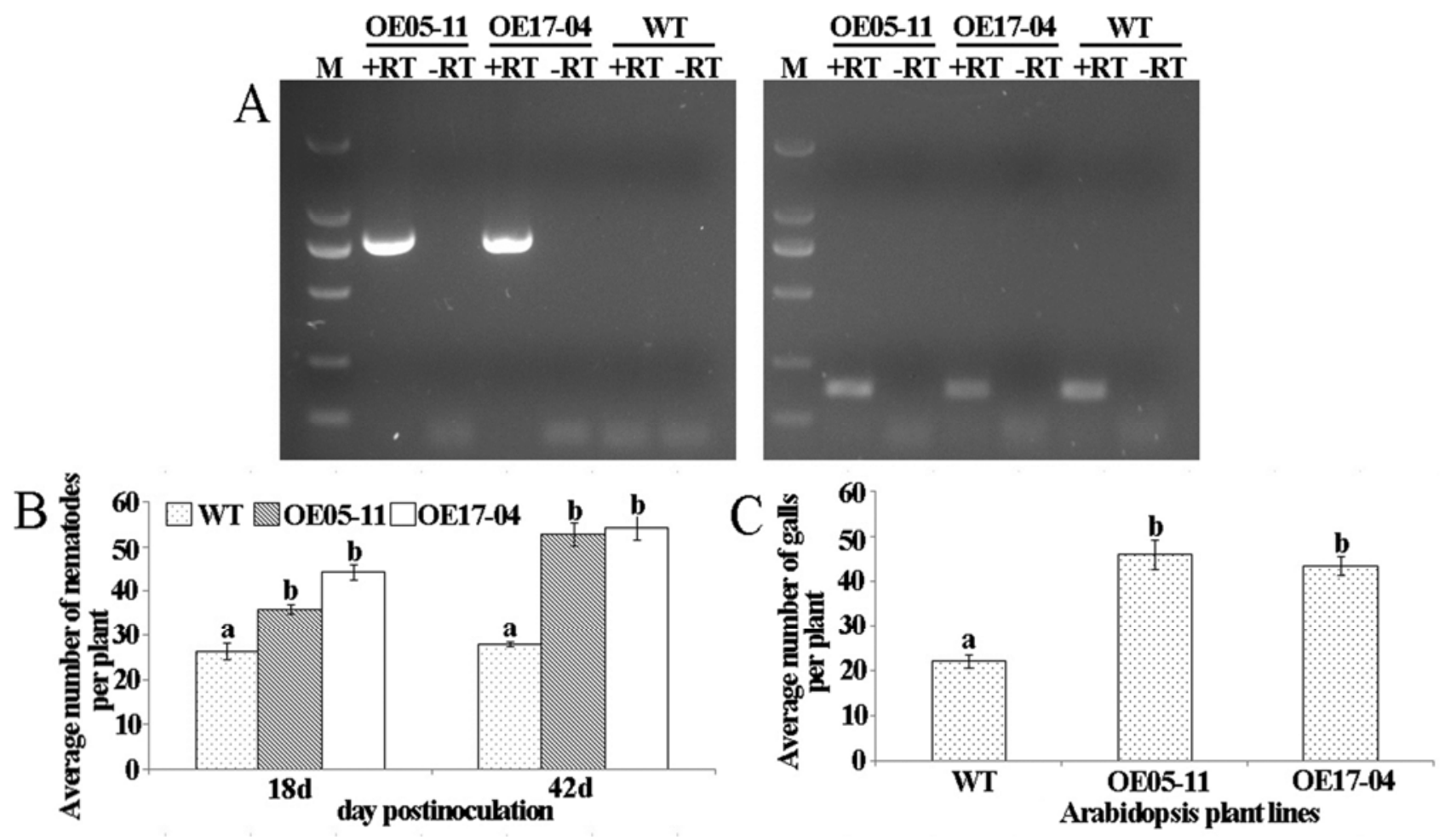

Fig. 8. Constitutive expression of the Mj-nulgla in independent transgenic lines (OE05-11 and OE17-04) of Arabidopsis thaliana increases plant susceptibility to infection by Meloidogyne javanica. A, Reverse-transcriptase (RT) polymerase chain reaction confirmed the expression of Mj-nulgla in transgenic Arabidopsis lines OE05-11 and OE17-04 compared with wild-type (WT) control in the absence (-RT) and presence (+RT), respectively, of RT. Amplification of $M j$ nulgla (left) and Arabidopsis $\beta$-actin (right). B, Arabidopsis lines expressing Mj-nulgla showed an increased number of nematodes in roots compared with WT controls. C, Arabidopsis lines expressing $M j$-nulg $1 \mathrm{a}$ showed increased galls in roots compared with WT plants. Columns for the same time point marked with different letters are significantly different $(P<0.05)$ from each other. 
which has further underpinned the critical role of the $\mathrm{MJ}$ NULG1a effector in the nematode parasitism.

In summary, we obtained a novel secretory protein (MJNULG1a) expressed in the dorsal glands of $M$. javanica, and which had the highest expression at par-J2 (5 dpi) and was secreted into host plants and targeted to the giant cell nuclei. Mj-nulgla appears to be unique for Meloidogyne spp. RNAi silencing of $M j$-nulgla could reduce the parasitism ability of M. javanica, whereas overexpression of $M j$-nulgla could enhance susceptibility of Arabidopsis to M. javanica. These findings suggest a potential regulatory role of MJ-NULG1a effector within the host nuclei to induce giant cell formation, maintain giant cells, and promote $M$. javanica parasitism. To our knowledge, this is only the second example of an RKN effector protein experimentally demonstrated to be localized in giant cell nuclei. Further studies should be conducted on the likely interaction between the MJ-NULG1a effector and a putative receptor in the host plant cells. Using in planta RNAi, we also demonstrated the importance of Mj-nulgla in RKN parasitism and its potential for producing transgenic plants with resistance to nematodes. It has been documented that in vivo expression of 16D10 double-stranded RNA in Arabidopsis resulted in effective plant resistance against four major RKN species (Huang et al. 2006a). Because Mj-nulgla is probably specific and conserved across RKN species, it could be used to generate transgenic plants with a wide-spectrum and specific resistance against RKN species.

\section{MATERIALS AND METHODS}

\section{Nematodes.}

M. javanica were collected from towel gourd (Luffa sp.) in Guangxi, China, and reared on tomato (Solanum lycopersicum) plants in greenhouses at $25^{\circ} \mathrm{C}$. Pre-J2 and parasitic stages were collected as described previously (Huang et al. 2005b). Tomato 'Xiahong No. 1' was used in nematode culture and other experiments conducted in this study.

\section{Gene amplification.}

The library enriched in cDNA fragments from pre-J2 was constructed by SSH with pre-J2 and eggs of $M$. javanica. To construct the library, approximately 20,000 pre-J2 and eggs were ground in liquid nitrogen. Total RNA samples were prepared separately from the pre-J2 and eggs using TRIzol following the manufacturer's instructions (Invitrogen, CA, U.S.A.) and DNA residues were removed by treatment with DNase I (Takara, Shiga, Japan). cDNAs were synthesized using a BD SMART PCR cDNA synthesis kit (Clontech, Mountain View, CA, U.S.A.) according to the manufacturer's protocol. SSH was performed using a PCR-Select cDNA subtraction kit (Clontech) according to the manufacturer's protocol. cDNA from eggs was used as a driver, and cDNA from pre-J2 was used as a tester to identify the genes upregulated at pre-J2 stage. The amplified cDNA fragments from the secondary PCR were ligated into the pGEM-T vector (Promega, Shanghai, China) and then introduced into Escherichia coli JM109-competent cells. Clones were selected and the inserts amplified by PCR using vector primers (M13 forward and reverse). The PCR products were analyzed by gel electrophoresis, then arrayed in duplicate by manually spotting onto Hybond- $\mathrm{N}^{+}$nylon membranes (Amersham Pharmacia Biotech, Pittsburgh) and incubated at $80^{\circ} \mathrm{C}$ for $2 \mathrm{~h}$. Then, arrays were screened by reverse Northern blots to validate the differential expression pattern of the gene fragments isolated from the library. A Random Primer DNA Labeling kit (Takara) was used to label the cDNA templates from eggs and pre-J2 for synthesizing probe-E and probe-J, respectively. The probe-E and
probe-J labeled with $\mathrm{a}^{32} \mathrm{P}$ deoxycycidine triphosphate were hybridized with the PCR fragments arrayed on membranes. In total, 59 clones upregulated at pre-J2 stage showing over twofold differences in hybridization signals were selected for sequencing analysis. A previously unreported EST of $436 \mathrm{bp}$ showing similarity to the sequences in Meloidogyne EST databases was selected for analysis in this study. The full-length sequence of this EST was obtained by TAIL-PCR and RACE, as described below.

$M$. javanica genomic DNA and total RNA were isolated using the Genomic DNA purification kit (Shenergy Biocolor, Shanghai, China) and TRIzol reagent (Invitrogen), respectively, after grinding pre-J2 in a $1.5-\mathrm{ml}$ sterile tube with liquid nitrogen. RNA was treated with DNase I (Takara) at $37^{\circ} \mathrm{C}$ for $30 \mathrm{~min}$, and the precipitated RNA pellet was resuspended in diethylpyrocarbonate-treated $\mathrm{H}_{2} \mathrm{O}$. The 3 '-RACE-Ready cDNA was synthesized from $1 \mu \mathrm{g}$ of total RNA with a BD SMART RACE cDNA amplification kit (Takara). Based on the obtained sequence of 436-bp EST described above, the primers D153R1 and D153R2 were designed. The $3^{\prime}$-terminal sequence was amplified by PCR using D153R1 and the $3^{\prime}$-anchor UPM primer, followed by a second-round PCR with D153R2 and NUP primers using the first-round PCR products as template. PCR was performed following the BD SMART RACE CDNA amplification kit user manual. To obtain a $5^{\prime}$-terminal sequence, TAIL-PCR was performed using the three reverse gene-specific primers D15T1, D15T2, and D15T3, as described previously (Liu et al. 2007). To confirm the sequence, primers covering the ORF, D15cdsF and D15cdsR, were designed to perform PCR from cDNA and DNA templates. For PCR amplification, $0.1 \mu \mathrm{g}$ of cDNA or DNA template was used in a $50-\mu 1$ reaction mixture consisting of $1 \times$ PCR buffer for KOD-plus-neo, 0.2 $\mathrm{mM}$ each dNTP, $1.5 \mathrm{mM} \mathrm{MgSO}{ }_{4}, 0.3 \mu \mathrm{M}$ primers, and 1 unit of KOD-plus-neo DNA polymerase (TOYOBO, Osaka, Japan). PCR conditions were as follows: predenaturation at $94^{\circ} \mathrm{C}$ for $30 \mathrm{~s} ; 30$ cycles of denaturation at $94^{\circ} \mathrm{C}$ for $30 \mathrm{~s}$, annealing at $60^{\circ} \mathrm{C}$ for $30 \mathrm{~s}$, and polymerization at $68^{\circ} \mathrm{C}$ for $2 \mathrm{~min}$; with a final incubation step at $16^{\circ} \mathrm{C}$. All primers used in this study were synthesized by Invitrogen Biotechnology Co. Ltd. (Shanghai, China) and are listed in Supplementary Table 1.

\section{DNA sequencing and analysis.}

PCR amplification products were purified with a universal DNA purification kit (Tiangen Biotech, Beijing) and the fragments were separately cloned into the pMD 18-T vector (Takara) and sequenced. Sequencing reactions were run on an AB3730 Stretch DNA sequencing system (Applied Biosystems, Foster City, CA, U.S.A.). The sequence homology of the predicted protein was analyzed using a BLASTn or BLASTx search of the nonredundant and EST NCBI databases. Sequences were aligned with CLUSTALW and the signal peptide was predicted using SignalP (Nielsen et al. 1997). Molecular mass and pI were predicted using ProtParam (Wilkins et al. 1998), while NLS domains were predicted through PSORT II (Nakai and Horton 1999) and WoLF PSORT (Horton et al. 2006).

\section{Southern hybridization.}

The total genomic DNA samples $(10 \mu \mathrm{g}$ each) from $M$. javanica, $M$. enterolobii, and $M$. incognita were separately digested with EcoRI and $X b a I$ before separation by electrophoresis on a $0.7 \%$ (wt/vol) agarose gel and transferred to Hybond $\mathrm{N}^{+}$membranes (Amersham-Biosciences, Little Chalfont, Buckinghamshire, England) (Sambrook et al. 1989), whereas the same amount of DNA samples from $H$. glycines, B. xylophilus, and $C$. elegans was digested with EcoRI only. The membrane was hybridized with the full-length $M j$-nulgla DNA from $M$. 
javanica. The probe was prepared with the DIG High Prime DNA Labeling and Detection Starter Kit II (Roche Applied Science, Mannheim, Germany). Hybridization was carried out at $65^{\circ} \mathrm{C}$ and the membrane was washed to a final stringency with $0.2 \times \mathrm{SSC}(1 \times \mathrm{SSC}$ is $0.15 \mathrm{M} \mathrm{NaCl}$ plus $0.015 \mathrm{M}$ sodium citrate) and $0.1 \%(\mathrm{wt} / \mathrm{vol}) \mathrm{SDS}$ at $65^{\circ} \mathrm{C}$; then, the membrane was blocked and incubated with anti-DIG antibody conjugated with alkaline phosphatase, and the membrane was developed according to the user manual.

\section{Developmental expression analyses.}

RNA samples were prepared from $100 \mathrm{M}$. javanica nematodes at different life stages as indicated, using the RNA prep micro kit (Tiangen Biotech). The first-strand cDNA was synthesized as described above. Quantitative PCR was performed using the Applied Biosystems 7500 real-time PCR system and the primer pairs qD15AF/qD15AR for amplifying the $M j$ nulgla fragment of $143 \mathrm{bp}$ or qactinF/qactinR for amplifying the $\beta$-actin fragment of $152 \mathrm{bp}$ as internal control. Mj-nulgla has a homologous gene according to $\mathrm{Mj}$-nulgla Southern hybridization; therefore, the homologous gene named $M j-n u l g l b$ was also obtained and used for sequence alignment with $M j$ nulgla (Supplementary Fig. S4) to design the Mj-nulgla-specific primer qD15AF. Quantitative PCR was performed with the following conditions: $95^{\circ} \mathrm{C}$ for $5 \mathrm{~min}$ and 40 cycles of $95^{\circ} \mathrm{C}$ for $15 \mathrm{~s}, 60^{\circ} \mathrm{C}$ for $15 \mathrm{~s}$, and $72^{\circ} \mathrm{C}$ for $32 \mathrm{~s}$, using the SYBR Green PCR Master Mix (TOYOBO). Quantification of the relative changes in gene expression was performed using the $2^{-\Delta \Delta \mathrm{CT}}$ method (Livak et al. 2001). The experiments were repeated three times, with three technical replicates for each reaction.

\section{Subcellular localization.}

The Mj-nulgla gene with or without signal peptide-encoding regions was amplified using the primer pairs D15cdsFSal/ D15cdsRNCO or D15nsFSal/D15cdsRNCO, respectively. The same PCR conditions were used as described above for the fulllength DNA amplification. The PCR products were digested with SalI and NcoI and inserted into pGFP digested with the same enzymes for generating D15S::pGFP and D15NS::pGFP. Then, D15S::pGFP, D15NS::pGFP, and pGFP were digested with BamHI and cloned into pCambia 1300 digested with the same enzymes. The constructs were transformed into the $A$. $t u$ mefaciens EHA105. The A. tumefaciens-mediated transient gene expression analysis on tomato plants was performed as described previously ( $\mathrm{Li}$ et al. 2009). The fused proteins were observed under a Leica TCS SP2 laser-scanning confocal microscope.

\section{Anti-MJ-NULG1a polyclonal serum production and analysis.}

For obtaining purified MJ-NULG1a protein, the Mj-nulgla cDNA was amplified using the primer pair D15YS/D15YR. The PCR products were digested with BamHI and HindIII and inserted into pET28a digested with the same enzymes for generating D15::pET28a. The construct was transformed into E. coli BL21 (DE3), and the recombinant E. coli was cultivated on 1 liter of Luria Bertani broth with $100 \mathrm{mM}$ kanamycin sulfate and $0.1 \mathrm{mM}$ isopropyl-thio-galactophranoside at $37^{\circ} \mathrm{C}$ to express the recombinant MJ-NULG1a. The recombinant protein with $6 \mathrm{X}$ his-tag at the $\mathrm{N}$ terminus was purified by affinity chromatography using $\mathrm{Ni}^{2+}$ NTA agarose (Qiagen, Shanghai, China) according to the user manual (QIAexpressionist). The amount of the purified recombinant protein was estimated by the Bradford method and its purity was determined by SDS-PAGE.

The MJ-NULG1a protein minus signal peptide obtained above was used as an immunogen to immunize rabbits intra- dermally for antiserum production, as described previously (Luciano et al. 2004). The purified MJ-NULG1a was mixed with complete Freund's adjuvant (Sigma-Aldrich, St. Louis) and used for primary injection at one subcutaneous point and two intramuscular points $(20 \mu \mathrm{g}$ of protein was divided into three parts). As a booster for the second, third, and fourth injections, the mixture containing MJ-NULG1a and incomplete Freund's adjuvant (Sigma-Aldrich) was similarly injected at 10-day intervals. Seven days after the last immunization, blood was collected and antiserum was collected. The immunoreactivity and the specificity of the serum were checked by Western blots. For Western blots, $10 \mu \mathrm{g}$ of total proteins from preparasitic $\mathrm{J} 2$, the galls from the tomato at 7 days after inoculation with $M$. javanica, and healthy tomato roots were separated on $12 \%$ SDS-PAGE gel and transferred to a nitrocellulose membrane (PALL, Washington, NY, U.S.A.). The membranes were blocked and incubated with anti-MJ-NULG1a serum and pre-immune serum and soaked in the anti-rabbit horseradish peroxidase conjugated secondary anti-body (Biosynthesis Biotechnology Co., Beijing), and the membranes were developed as described previously (Jaubert et al. 2005).

\section{Immunolocalization on $M$. javanica and sections of tomato galls.}

For immunolocalization on $M$. javanica, 10,000 freshly hatched $\mathrm{J} 2$ and 100 par-J3s (isolated from tomato galls 10 days postinoculation) were used for immunolocalization. Immunolocalization was carried out as described previously (Jaubert et al. 2002b).

For immunolocalization on sections of tomato galls, tomato galls infected with $M$. javanica of different life stages were collected and fixed in $4 \%$ formaldehyde in phosphate-buffered saline (PBS) buffer ( $\mathrm{pH} 7.5$ ) for $24 \mathrm{~h}$ at $4^{\circ} \mathrm{C}$. Following a previous description (Bachand and Castello 2008), the galls were sliced and the paraffin was removed.

Sections were soaked in $0.01 \mathrm{M}$ citric acid buffer ( $\mathrm{pH}$ 6.0) containing $3 \% \mathrm{H}_{2} \mathrm{O}_{2}$ for $10 \mathrm{~min}$ to block endogenous peroxidase activity, washed three times in $0.01 \mathrm{M}$ citric acid buffer ( $\mathrm{pH}$ 6.0) for $5 \mathrm{~min}$, soaked in $0.01 \mathrm{M}$ citric acid buffer, and heated slowly up to $95^{\circ} \mathrm{C}$. They were then incubated at $95^{\circ} \mathrm{C}$ for $20 \mathrm{~min}$ and subsequently cooled naturally to room temperature. Sections were then incubated in blocking solution (10\% bovine serum albumen diluted in 0.01 M PBS, $\mathrm{pH} 7.5$ ) for 30 min at $37^{\circ} \mathrm{C}$, and transferred to primary antibody solution (anti-MJ-NUGL1a serum diluted 50-fold in $0.01 \mathrm{M}$ PBS) for $8 \mathrm{~h}$ at $4{ }^{\circ} \mathrm{C}$ (for control, the gall sections were incubated in $2 \%$ preimmune rabbit serum). They were washed three times for $5 \mathrm{~min}$ using PBS, incubated in secondary antibody solution (goat-antirabbit immunoglobulin $\mathrm{G}$ conjugated with horseradish peroxidase [HRP]) for $30 \mathrm{~min}$ at room temperature, and washed five times for $5 \mathrm{~min}$. The sections were then placed in HRP-diaminobenzidine substrate solution for $15 \mathrm{~min}$ and eventually washed with water to stop the reaction. Sections were observed under a light microscope (CX21, Olympus, Tokyo).

\section{In planta RNAi.}

Two fragments of 319 and 304 bp of the Mj-nulgla gene were amplified by PCR using the primer pairs D15RNAiF3/ D15RNA322R and D15RNAF398/D15RNAR702, respectively. The two fragments were digested using $X b a \mathrm{I}$ and $S a c \mathrm{I}$, and inserted into pTRV2 digested with the same enzymes for generating pTRV2::nulg ${ }^{1 \mathrm{st}}$ and pTRV2::nulg ${ }^{2 \text { nd }}$. The vectors pTRV1, pTRV2, pTRV2::nulg ${ }^{1 s t}$, and pTRV2::nulg ${ }^{\text {nd }}$ were transformed into the A. tumefaciens EHA105. Tomato plants were infected with the virus by coagroinfiltration with $A$. tumefaciens EHA105 carrying the corresponding constructs described above using the previously described procedures (Ryu 
et al. 2004). In order to test whether the virus invasion was successful, the TRV coat protein was detected by PCR using cDNA that was reverse transcribed from RNA extracted from freshly grown parts of the plants as template, and by using the primer pair TRVcpF/TRVcpR 14 dpi (Anand et al. 2007). For each treatment, RNA was extracted from 100 par-J2 collected 5 dpi using the RNAprep micro kit (Tiangen Biotech). Firststrand cDNA was synthesized as described above. RT-PCR was performed to quantify the silencing efficiency using the primer pairs qD15AF/qD15AR and qactinF/qactinR. The same conditions described for full-length DNA amplification were used, except that polymerization was at $72^{\circ} \mathrm{C}$ for $30 \mathrm{~s}$ and reaction was completed for 28 cycles. Each PCR product $(5 \mu \mathrm{l})$ was analyzed on a $2 \%$ agarose gel by electrophoresis, and the amount of each band was measured by software AlphaEase FC, version 4.1.0. The relative expression levels were converted by dividing the amount of $M j$-nulgla by the amount of the control gene $\beta$-actin. Independent RT-PCR experiments were repeated twice.

To test the parasitism ability of Mj-nuglla-silenced nematodes, 100 tomato plants were agroinfiltrated with pTRV2::nulg ${ }^{1 \text { st }}$ or pTRV2::nulg ${ }^{\text {2nd }}$, and 100 tomato plants were agroinfiltrated with pTRV2 or untreated as control. Each plant was inoculated with 200 pre-J2 nematodes. After washing and staining with acid fushin, parasitic nematodes at 5, 10, 18, and $42 \mathrm{dpi}$; galls at 18 and $42 \mathrm{dpi}$; and eggs at 42 dpi were counted in tomato plant roots, with 10 tomato plants being collected at each time point. The same experiments were repeated three times. Statistically significant differences between each treatments and the corresponding control were determined by Duncan's multiple-range test $(P<0.05)$ using SAS version 9.2.

\section{Generation of transgenic Arabidopsis plants.}

The Mj-nulgla gene without the signal peptide-encoding region was amplified using the primer pair D15nsFSal/ D15cdsRSPH. The PCR products were digested with SalI and SphI and inserted into pGFP digested with the same enzymes for generating D15nS::pGFP-. Then, the construct was digested with BamHI and cloned into pCambia1300 digested with the same enzyme for generating pCambia-D15nS::pGFP-. The construct was introduced into A. tumefaciens EHA105 and used for transformation of Arabidopsis thaliana ecotype Columbia-0 (Col-0) by using the floral dip method (Zhang et al. 2006b). Transformed T1 plants were screened on Murashige and Skoog (MS) solidified medium containing hygromycin at $25 \mathrm{mg} \mathrm{liter}^{-1}$. Homozygous T3 seed were collected from T2 lines after segregation analysis on hygromycin-containing medium and used in this study. RT-PCR was conducted to confirm the presence of expressed Mj-nulgla transcripts in the transformed plants. RNA samples were extracted from $50 \mathrm{ng}$ of Arabidopsis using the RNA prep micro kit. The first-strand cDNA was synthesized as described above. RT-PCR was performed used the primer pairs D15cdsRNCO/D15nsFSal and AtactinF/AtactinR. For PCR amplification, $0.1 \mu \mathrm{g}$ of cDNA template was used in a $50-\mu 1$ reaction mixture consisting of $1 \times$ PCR buffer for Blend Taq, $0.2 \mathrm{mM}$ each dNTP, $0.3 \mu \mathrm{M}$ primers, and 1 unit of Blend Taq (TOYOBO). PCR conditions used were as follows: predenaturation at $94^{\circ} \mathrm{C}$ for $30 \mathrm{~s} ; 30$ cycles of denaturation at $94^{\circ} \mathrm{C}$ for $30 \mathrm{~s}$, annealing at $60^{\circ} \mathrm{C}$ for $30 \mathrm{~s}$, and polymerization at $72^{\circ} \mathrm{C}$ for $1 \mathrm{~min}$; with a final incubation step at $16^{\circ} \mathrm{C}$. Each PCR product $(5 \mu \mathrm{l})$ was analyzed on a $1.5 \%$ agarose gel by electrophoresis. Transgenic Arabidopsis seed and the wild-type control were planted on the sterilized sand and 30-day-old seedlings were inoculated with approximately 500 preparasitic $\mathrm{J} 2$ of $M$. javanica per plant, as described above. To test the susceptibility of transgenic plants, the roots of Arabidopsis were collected at 18 and $42 \mathrm{dpi}$, then washed prior to staining with acid fushin, and the parasitic nematodes in the roots and galls, respectively, were counted. Statistically significant differences in the mean $(n=10)$ between transgenic plant lines and the corresponding wild-type controls were determined by Duncan's multiple-range test $(P<0.05)$ using SAS version 9.2.

\section{ACKNOWLEDGMENTS}

This work was supported by grants from National Key Basic Research Program of China (973 Program) (number 2013CB127501), the Genetically Modified Organisms Breeding Major Projects (number 2009ZX08009045B), National Nature Science Foundation of China (numbers 31171824 , 31071666 , and 30871628 ), and the special fund for agro-scientific research in the public interest of China (number 201103018). We thank X. Wang at Cornell University and E. L Davis at North Carolina State University for their helpful comments and suggestions.

\section{LITERATURE CITED}

Abad, P., Gouzy, J., Aury, J. M., Castagnone-Sereno, P., Danchin, E. G. J., Deleury, E., Perfus-Barbeoch, L., Anthouard, V., Artiguenave, F., Blok, V. C., Caillaud, M. C., Coutinho, P. M., Dasilva, C., De Luca, F., Deau, F., Esquibet, M., Flutre, T., Goldstone, J. V., Hamamouch, N., Hewezi, T., Jaillon, O., Jubin, C., Leonetti, P., Magliano, M., Maier, T. R., Markov, G. V., McVeigh, P., Pesole, G., Poulain, J., Robinson-Rechavi, M., Sallet, E., Ségurens, B., Steinbach, D., Tytgat, T., Ugarte, E., van Ghelder, C., Veronico, P., Baum, T. J., Blaxter, M., Bleve-Zacheo, T., Davis, E. L., Ewbank, J. J., Favery, B., Greiner, E., Henrissat, B., Jones, J. T., Laudet, V., Maule, A. G., Quesneville, H., Rosso, M. N., Schiex, T., Smant, G., Weissenbach, J., and Wincker, P. 2008. Genome sequence of the metazoan plant-parasitic nematode Meloidogyne incognita. Nat. Biotechnol. 8:909-915.

Adam, M. A. M., Phillips, M. S., Tzortzkakis, E. A., and Blok, V. C. 2009. Characterisation of mjap genes encoding novel secreted proteins from the root-knot nematodes, Meloidogyne javanica. Nematology 11:253-265.

Anand, A., Krichevsky, A., Schornack, S., Lahaye, T., Tzfira, T., Tang, Y., Citovsky, V., and Mysorea, K. S. 2007. Arabidopsis VIRE2 INTERACTING PROTEIN2 is required for Agrobacterium T-DNA integration in plants. Plant Cell 19:1695-1708.

Bachand, G. D., and Castello, J. D. 2001. Immunolocalization of tomato mosaic tobamovirus in roots of red spruce seedlings. J. Phytopathol. 149:415-419.

Bellafiore, S., Shen, Z. X., Rosso, M. N., Abad, P., Shih, P., and Briggs, S. P. 2008. Direct identification of the Meloidogyne incognita secretome reveals proteins with host cell reprogramming potential. PLoS Pathog. 4:e1000192.

Bird, D. M., Williamson, V. M., Abad, P., McCarter, J., Danchin E. G. J. Castagnone-Sereno, P., and Opperman, C. H. 2009. The genomes of root-knot nematodes. Annu. Rev. Phytopathol. 47:333-351.

Dautova, M., Rosso, M. N., Abad, P., Gommers, F. J., Bakker, J., and Smant, G. 2001. Single pass cDNA sequencing-a powerful tool to analyse gene expression in preparasitic juveniles of the southern root-knot nematode Meloidogyne incognita. Nematology 3:129-139.

Davis, E. L., Hussey, R. S., Baum, T. J., Bakker, J., Schots, A., Rosso, M. N., and Abad, P. 2000. Nematode parasitism genes. Annu. Rev. Phytopathol. 38:341-372.

Davis, E. L., Hussey, R. S., and Baum, T. J. 2004. Getting to the roots of parasitism by nematodes. Trends Parasitol. 20:134-141.

Davis, E. L., Hussey, R. S., Mitchum, M. G., and Baum, T. J. 2008. Parasitism proteins in nematode-plant interactions. Curr. Opin. Plant Biol. 11:360-366.

Ding, X., Shields, J., Allen, R., and Hussey, R. S. 1998. A secretory cellulose-binding protein from the root-knot nematode (Meloidogyne incognita). Mol. Plant-Microbe Interact. 11:952-959.

Ding, X., Shields, J., Allen, R., and Hussey, R. S. 2000. Molecular cloning of a venom allergen AG5-like cDNA from Meloidogyne incognita. Int. J. Parasitol. 30:77-81.

Doyle, E. A., and Lambert, K. N. 2002. Cloning and characterization of an esophageal-gland-specific pectate lyase from the root-knot nematode Meloidogyne javanica. Mol. Plant-Microbe Interact. 15:549-556.

Dubreuil, G., Magliano, M., Deleury, E., Abad, P., and Rosso, M. N. 2007. Transcriptome analysis of root-knot nematode functions induced in the early stages of parasitism. New Phytol. 176:426-436.

Elling, A. A., Davis, E. L., Hussey, R. S., and Baum, T. J. 2007. Active uptake of cyst nematode parasitism proteins into the cell nucleus. Int. J. Parasitol. 37:1269-1279. 
Gao, B. L., Allen, R., Maier, T., Davis, E. L., Baum, T. J., and Hussey, R. S. 2003. The parasitome of the phytonematode Heterodera glycines. Mol. Plant-Microbe Interact. 16:720-726.

Hamamouch, N., Li, C., Hewezi, T., Baum, T. J., Mitchum, M. G., Hussey, R. S., Vodkin, L. O., and Davis, E. L. 2012. The interaction of the novel $30 \mathrm{C} 02$ cyst nematode effector protein with a plant $\beta$-1,3-endoglucanase may suppress host defence to promote parasitism. J. Exp. Bot. 63:36833695

Hewezi, T., Howe, P., Maier, T. R., Hussey, R. S., Mitchum, M. G., Davis, E. L., and Baum, T. J. 2008. Cellulose binding protein from the parasitic nematode Heterodera schachtii interacts with Arabidopsis pectin methylesterase: Cooperative cell wall modification during parasitism. Plant Cell 20:3080-3093.

Hewezi, T., Howe, P., Maier, T. R., Hussey, R. S., Mitchum, M. G., Davis, E. L., and Baum, T. J. 2009. Arabidopsis spermidine synthase is targeted by an effector protein of the cyst nematode Heterodera schachtii. Plant Physiol. 152:968-984.

Horton, P., Park, K. J., Obayashi, T., and Nakai, K. 2006. Protein subcellular localization prediction with WoLF PSORT. Pages 39-48 in: Proc. Asian Pac. Bioinf. Conf. Taipei.

Huang, G. Z., Gao, B. L., Maier, T., Allen, R., Davis, E. L., Baum, T. J., and Hussey, R. S. 2003. A profile of putative parasitism genes expressed in the esophageal gland cells of the root-knot nematode Meloidogyne incognita. Mol. Plant-Microbe Interact. 16:376-381.

Huang, G. Z., Dong, R. H., Allen, R., Davis, E. L., Baum, T. J., and Hussey, R. S. 2005a. Developmental expression and molecular analysis of two Meloidogyne incognita pectate lyase genes. Int. J. Parasitol. 35:685692.

Huang, G. Z., Dong, R. H., Allen, R., Davis, E. L., Baum, T. J., and Hussey, R. S. 2005b. Two chorismate mutase genes from the root-knot nematode Meloidogyne incognita. Mol. Plant Pathol. 6:23-30.

Huang, G. Z., Allen, R., Davis, E. L., Baum, T. J., and Hussey, R. S. 2006a. Engineering broad root-knot resistance in transgenic plants by RNAi silencing of a conserved and essential root-knot nematode parasitism gene. Pro. Natl. Acad. Sci. U.S.A. 103:14302-14306.

Huang, G. Z., Dong, R. H., Allen, R., Davis, E. L., Baum, T. J., and Hussey, R. S. 2006b. A root-knot nematode secretory peptide functions s a ligand for a plant transcription factor. Mol. Plant-Microbe Interact. 19:463-470.

Hussey, R. S. 1989. Disease-inducing secretions of plant-parasitic nematodes. Annu. Rev. Phytopathol. 27:123-141.

Jaouannet, M., Barbeoch, L. P., Deleury, E., Magliano, M., Engler, G., Vieira, P., Danchin, E. G. J., Da Rocha, M., Coquillard, P., Abad, P., and Rosso, M. N. 2012. A root-knot nematode-secreted protein is injected into giant cells and targeted to the nuclei. New Phytol. 194:924-931

Jaubert, S., Laffaire, J. B., Abad, P., and Rosso, M. N. 2002a. A polygalacturonase of animal origin isolated from the root-knot nematode Meloidogyne incognita. FEBS (Fed. Eur. Biochem. Soc.) Lett. 522:109-112.

Jaubert, S., Ledger, T. N., Laffaire, J. B., Piotte, C., Abad, P., and Rosso, M. N. 2002b. Direct identification of stylet secreted proteins from rootknot nematodes by a proteomic approach. Mol. Biochem. Parasitol. 121:205-211.

Jaubert, S., Laffaire, J. B., Ledger, T. N., Escoubas, P., Amri, E. Z., Abad, P., and Rosso, M. N. 2004. Comparative analysis of two 14-3-3 homologues and their expression pattern in the root-knot nematode Meloidogyne incognita. Int. J. Parasitol. 34:873-880.

Jaubert, S., Milac, A. L., Petrescu, A., de Almeida-Engler, J., Abad, P., and Rosso, M. N. 2005. In planta secretion of a calreticulin by migratory and sedentary stages of root-knot nematode. Mol. Plant-Microbe Interact. 18:1277-1284.

Jones, J. T., Kumar, A., Pylypenko, L. A., Thirugnanasambandam, A., Castelli, L., Chapman, S., Cock, P. J. A., Grenier, E., Lilley, C. J., Phillips, M., and Blok, V. C. 2009. Identification and functional characterization of effectors in expressed sequence tags from various life cycle stages of the potato cyst nematode Globodera pallida. Mol. Plant Pathol. 10:815-828.

Kalderon, D., Roberts, B. L., Richardson, W. D., and Smith, A. E. 1984. A short amino acid sequence able to specify nuclear location. Cell 39:499509.

Kale, S. D., and Tyler, B. M. 2011. Entry of oomycete and fungal effectors into plant and animal host cells. Cell. Microbiol. 13:1839-1848.

Khang, C. H., Berruyer, R., Giraldo, M. C., Kankanala, P., Park, S. Y., Czymmek, K., Kang, S., and Valent, B. 2010. Translocation of Magnaporthe oryzae effectors into rice cells and their subsequent cell-tocell movement. Plant Cell 22:1388-1403.

Lambert, K. N., Allen, K. D., and Sussex, I. M. 1999. Cloning and characterization of an esophageal-gland-specific chorismate mutase from the phytoparasitic nematode Meloidogyne javanica. Mol. Plant-Microbe Interact. 12:328-336.

Ledger, T. N., Jaubert, S., Bosselut, N., Abad, P., and Rosso, M. N. 2006.
Characterization of a new beta-1,4-endoglucanase gene from the rootknot nematode Meloidogyne incognita and evolutionary scheme for phytonematode family 5 glycosyl hydrolases. Gene 382:121-128.

Li, J. F., Park, E., von Arnim, A. G., and Nebenführ A. 2009. The FAST technique: A simplified Agrobacterium-based transformation method for transient gene expression analysis in seedlings of Arabidopsis and other plant species. Plant Methods 5:6

Liu, Y. G., and Chen, Y. L. 2007. High-efficiency thermal asymmetric interlaced PCR for amplification of unknown flanking sequences. Biotechniques 43:649-656.

Livak, K. J., and Schmittgen, T. D. 2001. Analysis of relative gene expression data using real-time quantitative PCR and the $2^{-\Delta \Delta C T}$ method. Methods 25:402-408.

Long, H., Wang, X., and Xu, J. 2006a. Molecular cloning and life-stage expression pattern of a new chorismate mutase gene from the root-knot nematode Meloidogyne arenaria. Plant Pathol. 55:559-563.

Long, H., Wang, X., Xu, J., and Hu, Y. J. 2006b. Isolation and characterization of another cDNA encoding a chorismate mutase from the phytoparasitic nematode Meloidogyne arenaria. Exp. Parasitol. 113:106-111.

Luciano, M. N., da Silva, P. H., Chaim, O. M., dos Santos, V. L., Franco, C. R., Soares, M. F., Zanata, S. M., Mangili, O. C., Gremski, W., and Veiga, S. S. 2004. Experimental evidence for a direct cytotoxicity of Loxosceles intermedia (Brown spider) venom in renal tissue. J. Histochem. Cytochem. 52:455-467.

Mount, S. A. 1982. Catalogue of splice junction sequences. Nucleic Acids Res. 10:459-472.

Nakai, K., and Horton, P. 1999. PSORT: A program for detecting sorting signals in proteins and predicting their subcellular localization. Trends Biochem. Sci. 24:34-36.

Nielsen, H., Engelbrecht, J., Brunak, S., and Heijne, G. 1997. Identification of prokaryotic and eukaryotic signal peptides and prediction of their cleavage sites. Protein Eng. 10:1-6.

Opperman, C. H., Bird, D. M., Williamson, V. M., Rokhsar, D. S., Burke, M., Cohn, J., Cromer, J., Diener, S., Gajan, J., Graham, S., Houfek, T. D., Liu, Q., Mitros, T., Schaff, J., Schaffer, R., Scholl, E., Sosinski, B. R., Thomas, V. P., and Windham, E. 2008. Sequence and genetic map of Meloidogyne hapla: A compact nematode genome for plant parasitism. Pro. Natl. Acad. Sci. U.S.A. 105:14802-14807.

Patel, N., Hamamouch, N., Li, C., Hewezi, T., Hussey, R. S., Baum, T. J., Mitchum, M. G., and Davis, E. L. 2010. A nematode effector protein similar to annexins in host plants. J. Exp. Bot. 61:235-248.

Rosso, M. N., Favery, B., Piotte, C., Arthaud, L., De Boer, J. M., Hussey, R. S., Bakker, J., Baum, T. J., and Abad, P. 1999. Isolation of a cDNA encoding a $\beta-1,4$-endoglucanase in the root-knot nematode Meloidogyne incognita and expression analysis during plant parasitism. Mol. Plant-Microbe Interact. 12:585-591.

Rosso, M. N., Jones, J. T., and Abad, P. 2009. RNAi and functional genomics in plant parasitic nematodes. Annu. Rev. Phytopathol. 47:207232.

Roze, E., Hanse, B., Mitreva, M., Vanholme, B., Bakker, J., and Smant, G. 2008. Mining the secretome of the root-knot nematode Meloidogyne chitwoodi for candidate parasitism genes. Mol. Plant Pathol. 9:1-10.

Ryu, C. M., Anand, A., Kang, L., and Mysore, K. S. 2004. Agrodrench: A novel and effective agroinoculation method for virus-induced gene silencing in roots and diverse solanaceous species. Plant J. 40:322-331.

Sacco, M. A., Koropacka, K., Grenier, E., Jaubert, M. J., Blanchard, A., Goverse, A., Smant, G., and Moffett, P. 2009. The cyst nematode SPRYSEC protein RBP-1 elicits Gpa2-and RanGAP2-dependent plant cell death. PLos Pathog. 5:e1000564.

Sambrook, J., Fritsch, E. F., and Maniatis, T. 1989. Molecular Cloning: A Laboratory Manual, 2nd ed. Cold Spring Harbor Laboratory Press, Cold Spring Harbor, NY, U.S.A.

Sasser, J. N. 1980. Root-knot nematodes: A global menace to crop production. Plant Dis. 64:36-41.

Tytgat, T., Vanholme, B., De Meutter, J., Claeys, M., Couvreur, M., Vanhoutte, I., Gheysen, G., van Criekinge, W., Borgonie, G., Coomans, A., and Gheysen, G. 2004. A new class of ubiquitin extension proteins secreted by the dorsal pharyngeal gland in plant parasitic cyst nematodes. Mol. Plant-Microbe Interact. 17:846-852.

van Ooij, C., Tamez, P., Bhattacharjee, S., Hiller, N. L., and Harrison, T 2008. The malaria secretome: From algorithms to essential function in blood stage infection. PLoS Pathog. 4:e10000084.

Vieira, P., Danchin, E. G. J., Neveu, C., Crozat, C., Jaubert, S., Hussey, R. S., Engler, G., Abad, P., de Almeida-Engler, J., Castagnone-Sereno, P., and Rosso, M. N. 2010. The plant apoplasm is an important recipient compartment for nematode secreted proteins. J. Exp. Bot. 62:12411253.

Wang, J., Lee, C., Replogle, A., Joshi, S., Korkin, D., Hussey, R., Baum, T. J., Davis, E. L., Wang, X., and Mitchum, M. G. 2010. Dual roles for the variable domain in protein trafficking and host-specific recognition of 
Heterodera glycines CLE effector proteins. New Phytol. 187:1003-1017.

Wang, X., Li, H. M., Hu, Y. J., Fu, P., and Xu, J. 2007. Molecular cloning and analysis of a new venom allergen-like protein gene from the rootknot nematode Meloidogyne incognita. Exp. Parasitol. 117:133-140.

Wilkins, M. R., Gasteiger, E., Bairoch, A., Sanchez, J. C., Williams, K. I., and Hochstrasser, D. F. 1998. Protein identification and analysis tools in ExPASy server. In: 2-D Proteome Analysis Protocols, 2. A. J. Link, ed. Humana Press, Totowa, NJ, U.S.A.

Williamson, V. M., and Hussey, R. S. 1996. Nematode pathogenesis and resistance in plants. Plant Cell 8:1735-1745.

Wyss, U., Grundler, F. M. W., and Munch, A. 1992. The parasitic behavior of second-stage juveniles of Meloidogyne incognita in roots of Arabidopsis thaliana. Nematologia 38:98-111.

Zhang, X., Henriques, R., Lin, S. S., Niu, Q. W., and Chua, N. H. $2006 a$.
Agrobacterium-mediated transformation of Arabidopsis thaliana using the floral dip method. Nat. Protocols 1:1-6.

Zhang, Z. R., Liao, J. L., Cui, R. Q., Zhuo, K., Li, X. D., Zheng, J. J. Chen, H. Y., and Wang, X. 2006b. Cloning and sequence analysis of full-length cDNA of $\beta$-1,4-endoglucanase genes of Meloidogyne javanica. Acta Phytopathol. Sin. 36:517-522.

\section{AUTHOR-RECOMMENDED INTERNET RESOURCES}

Center for Biological Seqnence Analysis SignalP server: www.cbs.dtu.dk/services/SignalP

ExPASy ProtParam server: web.expasy.org/protparam

NCBI BLAST databases: www.ncbi.nlm.nih.Gov/BLAST 